\title{
A Mimesis Musical ${ }^{1}$
}

Katia Kato ${ }^{2}$

RESUMO: A música ocupa um lugar de destaque como um dos principais meios de imitação. A utilização da música como ferramenta para suscitar e representar afetos, preconizada desde os antigos, chega integralmente ao século XVIII, podendo ser observada claramente nas obras dos compositores alemães ligados à doutrina composicional da Musica Poetica ${ }^{3}$ e, sobretudo, na obra de Johann Sebastian Bach. Porém, diversas são as espécies de imitação musical, de forma que o intuito deste trabalho foi categorizar e definir a função das espécies imitativas, com base na concepção aristotélica de imitação e nas categorias de imitação propostas por Johann Mattheson, um dos principais teóricos da Musica Poetica, tentando demonstrar que, desde a concepção musical da antiguidade, música e poética são inseparáveis.

PALAVRAS-CHAVE: Mimesis musical. Aristóteles. Musica Poetica. Johann Sebastian Bach.

\section{A Imitação na Música}

$\mathrm{Na}$ concepção aristotélica sobre a gênese, as coisas "[...] são geradas naturalmente, outras artificialmente e outras espontaneamente." (Metafísica, 1032a1). Natureza, arte e acaso, portanto, são os princípios da produção, sendo a produção artificial, ou seja, aquela realizada a partir da arte, "[...] a geração das coisas cuja forma está contida na alma.” (Metafísica. 1032a1 -1032b1). Dessa forma, estabelece-se no pensamento aristotélico a noção de produção artística, ou poética, que é "[...] uma certa disposição produtora conformado por um princípio verdadeiro.” (Ética a Nicômaco, 1140a1 20).

\footnotetext{
${ }^{1}$ http://dx.doi.org/10.1590/S0101-31732016000500007

${ }^{2}$ Professora Doutora do curso de Licenciatura em Música da Faculdade Nazarena do Brasil, responsável pelas matérias de História da Música, História da Música do Brasil e Estética Musical. pkjusti@uol.com.br

${ }^{3}$ Doutrina composicional (Composicionslehre) criada na Alemanha, entre os séculos XV e XVI, pelos teóricos luteranos, entre eles: Nicolaus Listenius, Gallus Dressler e Joachim Burmeister, então influenciados pelos conceitos retóricos, éticos, políticos e poéticos do Renascimento humanista e por um reavivamento das disciplinas de linguística e retórica. Tal doutrina buscava unir a racionalidade e a proporcionalidade matemática da teoria da música aos conceitos e fundamentos da retórica, visando, através e pelo texto, a atingir, persuadir e afetar os ouvintes pela música executada. A Musica Poetica estabelecia-se como um conceito único de composição, o qual procurava um equilíbrio entre ciência e arte, ratio (razão) e sensus (sensibilidade), especulação e habilidade.
} 
Diferentemente de Platâo, Aristóteles concebe a poesia como verdade, ou seja, como validade ou eficácia nos processos cognitivos, ao considerar a poesia como tendência à imitação, inata aos homens, como manifestação da tendência ao conhecimento. Afirma ele (Poética, 1448b) que "[...] o imitar é congênito ao homem, sendo este entre todos os seres viventes, o mais imitador, apreendendo por imitação as suas primeiras noções de vida, e além disso, o homem se compraz no imitado.”

Aristóteles explica o problema da imitação (mimesis) como um problema da poética ou produção artística. A mimesis aristotélica significa toda forma de cópia ou produção do semelhante, da realidade. A imitação poética, sinônimo de imitação, não da fala, mas da ação, é "[...] algo de mais filosófico ${ }^{4}$ e mais sério do que a história, pois refere-se mais ao universal" (Poética, 1451b 36), pois, nela, o imitador ou artista, utilizando ritmo, linguagem e harmonia (Poética, 1447a 17), "[...] imita sobretudo açóes, com agentes humanos de elevada ou baixa índole" (Poética, 1448a 1-2), trazendo à tona, com base na verossimilhança e na necessidade, algo de validade universal. Para C. Segre (1989, p. 220), o conceito aristotélico de mimesis, que formaliza a relaçáo com a realidade, é complementar de uma concepção gnosiológica da arte, a qual faz produzir o prazer pelo reconhecimento e pela compreensão da realidade representada, celebrando como efeito conclusivo a catarse, superação das paixôes através do conhecimento. Enfatiza o autor que, “[...] assim, Aristóteles subordina à sua teoria gnosiológica, sem as negar, as orientaçôes hedonistas ou psicológicas possíveis, através da individuação de um ciclo mimese-prazerconhecimento."

A ação de imitar tem por núcleo a observação que se centraliza sobre o que há de mais peculiar na estrutura ativa do elemento humano, o caráter. A observação de diversos tipos humanos, de acordo com a variedade de caracteres existentes (normais, virtuosos, viciosos) fornece ao imitador o cimento para a construção de sua arte. Como uma das principais espécies de imitação, encontra-se a tragédia, que é a

[...] imitação de uma ação de caráter elevado, completa e de certa extensão, em linguagem ornamentada e com várias espécies de ornamentos distribuídas pelas diversas partes [do drama], [imitação que se efetua] não por narrativa, mas mediante atores, e que, suscitando o terror e a piedade, tem por efeito a purificação dessas emoçóes [catarse]. (Poética, 1449b 24).

\footnotetext{
${ }^{4}$ No sentido da busca da verdade filosófica.
} 
Aristóteles foi o primeiro pensador a utilizar o termo catarse para designar, além de um evento médico, no sentido de purgação e purificação corpórea, um fenômeno provocado por obra da poesia, particularmente na sua forma trágica, que provocaria uma libertação ou purificação dos afetos da alma.

No processo imitativo, a música que, segundo Aristóteles, é parte constitutiva da tragédia, tem função primordial, porque a música é a representação direta das emoçóes da alma que serão afetadas de acordo com o ethos do modo musical usado. Para ele, "[...] a música é, por sua natureza, uma das coisas que em si mesmas trazem o agrado." (Política, V/V \$10, 1966, p.165-166). "Há na música um prazer que toca à própria natureza, que encanta todas as idades, todos os caracteres, e que faz agradável o seu culto." Ela pode influenciar o coração e a alma, modificando nossos sentimentos, pois [...] desperta o entusiasmo na alma (\$5), possuindo "[...] o poder de alterar nossos gostos à sua vontade.” (\$4). A importância da utilização da música como meio de imitação de afetos é explicada na Política (V/V) (p.166):

\$6. Ora, náo há o que melhor imite os reais sentimentos da alma do que o ritmo e a melodia [...]. A prova do que dizemos está nos eventos porque a música faz nascer em nossa alma todas essas paixóes. [...]

\$8. A música é a imitação dos sentimentos morais, e isso é claro, pois existem diferenças intrínsecas na natureza dos diferentes acordes.

Se realizarmos uma análise sobre os usos, formas e elementos da poética, da qual a tragédia faz parte, podemos observar que todos os princípios relativos à produção artística e à imitação se enquadram também no que poderíamos chamar de princípios "poético-religiosos", cujo melhor exemplo de aplicação se encontra na missa católica.

A missa, enquanto poesia, imita o sacrifício, ação trágica onde estão presentes os binômios do castigo-consolação e morte-ressurreição, base das teologias cristãs, os quais, analogamente aos afetos do terror e piedade contidos na tragédia, assumem igualmente uma função catártica. Além disso, na missa se encontra também um processo pedagógico, realizado pela observação e vivenciamento da ação trágica. Se considerarmos ainda a música como parte constituinte da estrutura litúrgica da missa, sendo responsável por suscitar afetos nos fiéis, essa analogia é ainda mais próxima da forma trágica.

A imitação, que, como vimos, encontra na música um dos seus principais artifícios, tem sido empregada como ferramenta pedagógica, social 
e teológica desde os gregos na Antiguidade Clássica. Entre os séculos XVI e XVIII, a tradição grega foi fortemente revivida pelos teóricos, que passam a realizar a combinação entre antigas ideias filosóficas e retóricas, criando a base para uma visão dominante de que a música era, acima de tudo, a linguagem capaz de despertar os afetos.

No caso da música sacra, sobretudo a música reformada luterana, o recurso da imitaçáo musical, aliado aos preceitos retóricos do discurso, foi imprescindível como ferramenta teológica. A imitação musical da Reforma, cujo princípio básico aparece no "Sermão Sonoro", no qual a música é serva do texto, unia os princípios persuasivos contidos na retórica, com a imitação de ações da poética. Pela retórica musical, era possível representar afetos que deveriam mover os fiéis, persuadindo-os a afastar-se do pecado e conduzindo-os à virtude; pela poética do texto, era possível suscitar o terror e a piedade, que, através da catarse, analogamente ao espetáculo trágico, purgariam suas paixóes.

Vale ressaltar que a prática musical luterana, ainda praticada no período de Bach, revive a concepção de Aristóteles, onde poética e retórica estavam integradas. Esse fato se confirma a partir do próprio Aristóteles, quando, ao tratar da linguagem e do pensamento da obra literária, na Poética, nos remete à Retórica, afirmando que "[...] as questóes relativas ao pensamento encontram o seu lugar nos livros sobre a retórica" (Poética, 1456a 33-36). C. Segre (1989, p.221) corrobora essa afirmação, ao assinalar:

Reelaborada pelos romanos, até à Rhetorica ad Herennium e até Quintiliano, a retórica subentendida na Poética tornar-se-á na Idade Média argumento quase exclusivo dos tratadistas da literatura. As muitas obras com o título de Poetria, Ars versificatoria, etc. são substancialmente tratados de retórica.

E foram nesses princípios poéticos e retóricos, especialmente em sua forma aristotélica, que a música alemã do século XVIII, de Johann Sebastian Bach, se embasou. Nesse período, um dos principais seguidores dessas preceptivas foi o dramaturgo, literato e crítico alemão Johann Gottsched, cuja obra, fortemente influenciada pelos teóricos franceses, defendia a subordinação da poesia alemã aos princípios ordenadores propostos nas teorias poéticas de Aristóteles e Horácio.

Johann Gottsched (1962, p. 603) reiterava uma ideia antiga sobre a relação íntima entre música e poesia, e, em seu tratado Versuch einer Critischen Dichtkunst, de 1751, explica: 
Antigamente toda a poesia era unida com a música: assim a tragédia tem a sua origem a partir de certas canções que eram entoadas para homenagear Baco. Em dias festivos vários cantores, que uniam-se e compunham um coro, tocavam, dançavam e cantavam à maneira da religiáo pagã e ofereciam este culto ao deus do vinho. Porém, como normalmente tanto os cantores quanto o público se embriagavam, as cançóes entoadas não eram tão sérias, ao contrário, continham várias farsas. Quanto mais praticavam estas cançóes, mais se aperfeiçoavam e mais eram apreciados. Desta forma seu número aumentou e cada grupo procurava se destacar dos demais. Havia entre eles competiçóes e o prêmio era, como antigamente, ainda alto, sendo concedido ao melhor cantor um bode. Em grego bode chama-se $\tau \rho \alpha \gamma o \sigma$ e canto $\omega \delta \eta$, vindo daí a origem da palavra Tragédia, o "canto do bode", tal como Aristóteles testemunha na sua Poética e Horácio na sua poesia: "Aquele que disputou com um poema trágico um bode de preço vil. [...]”5

Sobre a origem da tragédia estar atrelada aos cantos rústicos, Paul Harvey (1987, p. 497) acredita que se deve procurá-la numa forma elementar coral e rústica de drama cultivada nos povoados da Ática, e que Téspis ${ }^{6}$ tenha introduzido, nesse drama, a parte do ator, fato ocorrido na segunda metade do século VI a.C., nas Grandes Dionisíacas, em Atenas. Provavelmente, a tragédia tenha surgido da fusão desse drama rústico com algum elemento lírico solene dos cantos corais dionisíacos.

Gottsched (1962, p. 603), claramente embasado nas Poéticas de Aristóteles e Horácio, que conheceu através dos autores franceses, concorda com o ponto de vista de que o surgimento e desenvolvimento da tragédia se deu a partir da execução das cançóes dos coros rústicos. Ele assevera:

\footnotetext{
${ }^{5}$ Wie vorzeiten die ganze Poesie mit der Musik vereinbaret gewesen: also hat auch die Tragödie ihren Ursprung aus gewissen Liedern, die dem Bacchus zu Ehren gesungen worden. Es traten an Festtagen etliche Sänger zusammen, die ein ganzes Chor ausmachten, diese spielten, tanzten und sungen nach Art der heidnischen Religion, dem Weingotte dadurch seinen Gottesdienst zu leisten. Wie sie aber gemeiniglich, sowohl als die Zuhörer, ein Räuschchen hatten: also waren auch ihre Lieder so ernsthaft nicht; sodern es liefen allerley Possen mit unter. Jemehr man sich in solchen Gesängen übte, je weiter brachte mans darinn: und desto lieber hörte man auch solchen Sängern zu. Daher kam es nun, daß sich ihre Zahl vermehrte; und da $\beta$ es eine Bande der andern zuvor zu thun suchte. Sie giengen wohl gar einen Wettstreit darüber ein, und der Preis war nach der alten Art schon gro $\beta$ genug, wenn man dem besten Sänger einen Bock zum Gewinnste zuerkannte. Ein Bock heist $\tau \rho \alpha \gamma o \sigma$, und ein Lied $\omega \delta \eta$; daher kömmt das Wort Tragödie, ein Bocklied, wie solches theils Aristoteles in seiner Poetik, theils Horaz in seiner Dichtkunst bezeugt [...]: Carmine qui tragico uilem certauit ob hircum.

${ }^{6}$ Poeta grego semilendário, cujo nome estava ligado a Icária, na Ática; floresceu por volta de 534 a.C. Segundo a tradiçẫo, Téspis introduziu um ator em espetáculos até então apresentados apenas com um coro, representando esse ator um personagem lendário ou histórico e dizendo uma fala previamente composta. Os autores posteriores a Aristóteles consideravam Téspis o inventor da tragédia (HARVEY, 1987, p. 486).
} 
\$2. Com o passar do tempo, o cantar permanente [dos coros] tornou-se cansativo e sentia-se falta de uma mudança. Téspis, que com seus cantores vagava pela Grécia de um lugar para o outro, pensou em algo novo; dividiu as cançôes e entre cada duas partes apresentava uma pessoa que fazia uma narrativa, mas sem cantar. Por motivos de comodidade, transformou sua carruagem em palco, colocando nela vigas onde seu pessoal poderia cantar e atuar de maneira que poderiam ser vistos e ouvidos de maneira melhor. Para que não fossem reconhecidos, ao invés de máscaras, passaram a utilizar levedura no rosto. Devido a estas mudanças, Téspis é considerado o inventor da tragédia. ${ }^{7}$

Gottsched continua ainda a discorrer sobre o aprimoramento das técnicas da tragédia e de como Ésquilo cria o protagonista:

Ésquilo, um poeta mais jovem, percebeu que as narrativas colocadas entre as cançōes ainda não eram tão agradáveis; seria mais agradável se [na narrativa] algumas pessoas falassem juntas para expressar variedade e mudança. Ao mesmo tempo ele pensou em vários adornos para as suas tragédias. Ele inventou outras máscaras, deu ao seu pessoal roupas nobres e construiu um palco melhor: porém a característica mais peculiar em Ésquilo foi que entre as pessoas atuantes havia uma ligação das conversas. Em tais peças, inventa também a ideia do personagem principal, o que anteriormente era apenas uma coisa confusa, sem nexo nem ordem. Isto é testemunhado por Aristóteles no seu IV Capítulo [da Poética ${ }^{8}$ e por Horácio [na Ars Poetica $]^{9}[\ldots]^{10}$.

${ }^{7}$ Man ward aber des beständigen Singens mit der Zeit überdrüßig, und sehnte sich nach einer Veränderung. Thespis, der mit seinen Sängern in Griechenland von einem Orte zum andern herumzog, erdachte etwas neues, als er die Lieder in Theile absonderte, und zwischen zweyen und zweyen allemal eine Person auftreten ließ, die etwas ungesungen erzählen mußte. Mehrerer Bequemlichkeit halber machte er seinen Wagen zur Schaubüne; indem er Bretter darüber legte, und seine Leute droben singen und spielen lie $\beta$, damit sie desto besser zu sehen und zu hören seyn möchten. Damit man aber dieselben nicht erkennen könnte; so salbte er ihnen die Gesicht mit Hefen, welche ihnen anstatt der Larven dienen mußten. Um dieser Veränderung halber wird Thespis für den Erfinder der Tragödie gehalten.

8 "Mas nascida de um princípio improvisado [...] [a tragédia] pouco a pouco foi evoluindo, à medida que se desenvolvia tudo quanto nela se manifestava; até que, passadas muitas transformaçóes, a tragédia se deteve, logo que atingiu a sua forma natural. Ésquilo foi o primeiro que elevou de um a dois o número dos atores, diminuiu a importância do coro e fez do diálogo protagonista. Sófocles introduziu três atores e a cenografia." (Poética, 1449a 20).

9 “Segundo consta, Téspis foi o inventor do até então ignorado gênero de Camena trágica e transportava em carretas poemas que atores cantavam e representavam de cara besuntada de borra. Após ele, Ésquilo, inventor da máscara e mantos nobres, estendeu tablados sobre pequenos caibros e ensinou como emitir voz forte e firmar-se nos coturnos."

${ }^{10}$ Aeschylus nämlich, ein neuerer Poet, sah wohl, daß auch die Erz"shlungen einzelner Personen, die man zwischen die Lieder einschaltete, noch nicht so angenehm wären; als wenn ein paar Personen mit einander 
As teorias de Gottsched foram uma das vias mais importantes da entrada e da circulação das Poéticas na Alemanha, no século XVIII. Através de seus libretos de cantatas, alguns musicados por Bach ${ }^{11}$, a fortuna da Poética inegavelmente alcança o compositor.

Por ser uma obra monumental e emblemática, a qual pode ser considerada como um compêndio de toda obra do compositor, a "Missa em Si Menor" de Bach serve como um ótimo exemplo da utilização dos ideais da poética, pois, além de estar inserida num contexto "poético-religioso", revelado pela própria tradição do rito católico, nela ainda se adotam exemplos de imitação musical encontrados nas mais diversas formas composicionais, como, por exemplo, música vocal, de dança, sacra, profana ou puramente instrumental. A obra contém uma "dupla identidade" religiosa, porque, apesar de usar um texto latino, sua música é inegavelmente de tradição composicional luterana, podendo ser tomada como um tropo realizado de acordo com os preceitos composicionais luteranos e católicos. Bach, ao compor sua Grande Missa Católica, assim denominada por seu filho Carl P.E. Bach, segue à risca os preceitos da Musica Poetica, os quais preveem a representação dos afetos do texto nela contido, uma prática corrente do século XVIII. Na "Missa em Si Menor", essa representação será feita com base nos afetos contidos no sacrifício, sendo, portanto, a representação musical do sacrifício. Assim, a "Missa em Si Menor" apresenta uma dupla forma de imitação trágica: uma proveniente da poética, através da imitação da ação do sacrifício, e a outra proveniente da retórica, por meio das representaçôes dos afetos contidos nos textos luteranos que seriam parodiados.

A “Missa em Si Menor" é uma obra monumental e, nela, o compositor lançou mão de várias formas composicionais que utilizam práticas imitativas retórico-musicais, tais como contrafactum, ${ }^{12}$ paródia, tropo, emulação etc.,

sprächen, darinn sicht mehr Mannigfaltigkeit und Veränderung würde anbringen lassen: und da ihm solches nach Wunsche ausshlug; so dachte er auch auf mehrere Zierrathe seiner Tragödien. Er erfand die Larven, gab seinen Leuten ehrbare Kleidungen, und bauete sich eine bessere Schaubühne: ja, welches das merkwürdigste war, so machte Aeschylus, da $\beta$ die Gespräche seiner auftretenden Personen mit einander zusamen hingen.Kurz, er erfand zuerst die Idee der Hauptperson in einem solchen Spiele, welches vorher nur ein verwirrtes Wesen ohne Verknüpfung und Ordnung gewesen war. Das bezeugt abermal Aristoteles in seinem IV. Capitel, und Horaz [...].

${ }^{11}$ A música do Agnus Dei da "Missa em Si Menor" é uma paródia feita a partir da música de um desses libretos de Gottsched musicados por Bach.

${ }^{12}$ Contrafactum, paródia, imitaçấo, emulação, tropo são formas imitativas que, embora possam nos remeter a procedimentos artísticos semelhantes, guardam em si algumas sensíveis diferenças. Elas se distinguem de acordo com sua aplicação em diversas áreas, seja no campo da literatura, seja da oratória ou ainda na composição musical. Inicialmente, foram adotadas como ferramenta pedagógica, 
que seguem tanto os conceitos de mimesis propostos por Aristóteles, em sua Poética, quanto as categorias de imitaçáo sugeridas pelo teórico Johann Mattheson, contemporâneo de Bach, descritas na terceira parte de seu tratado Der vollkommene Capellmeister de 1739:

Exatamente como numa discussão, na qual cada fala é respondida apenas com Sim ou Não, e na qual nenhum exame é efetuado, nenhuma asserção é apresentada, nenhum contra-argumento é discernido, nenhuma pequena amigável contestação apresentada, assim também, [na composição] quando absolutamente nenhum esforço for feito para imitar ou para destacar, logo se tornará em algo sonolento e causará um mau deleite; assim também ocorrerá em cada Harmonia, mesmo que ela seja constituída de somente duas vozes, certamente ainda exigirá tais explicaçóes, objeçóes, analogias e argumentos nos sons [música], que não temos como atender através de nenhum meio melhor, a não ser pela imitação, também conhecida por imitatio ou aemulatio vocum. Esta imitação tem três diferentes sentidos na música. No primeiro encontramos a oportunidade de imitar todos os tipos de coisas naturais e afecçóes de ânimo, que é, indubitavelmente, o maior auxílio para a inventio, como já discutimos acima. Desde que não se configure em nenhum roubo de forma musical, o segundo sentido referese aos problemas que temos na imitação de uma ou outra obra de mestre ou compositor. O terceiro sentido refere-se ao que pode ser observado através da imitação de agradáveis competições, nas quais diferentes vozes se guiam com toda a liberdade sobre conhecidas regras formais, motivos, passagens e frases. ${ }^{13}(\$ .3-4,331) .{ }^{14}$

por retóricos, literatos e compositores, que previam o ensino de técnicas composicionais do discurso falado, escrito ou sonoro. Através dos tempos, dos usos e costumes, os termos assumem conotaçóes variadas que se confundem ora com a homenagem, no caso da emulação e da imitação, ora com o plágio ou "roubo", como da paródia.

${ }^{13}$ \$.3. Denn, gleichwie eine Unterredung, da zu allen Vorträgen blosserdings Ja oder Nein gesaget, und keine Untersuchung vorgenommen, keine Behauptung angebracht, keine Gegenrede verspüret, kein kleiner freundlicher Streit erregt, ja, gar keine Mühe genommen wird, es einander nach oder auch zuvorzuthun, gar bald schläfrig macht, und schlechte Freude erwecket: also erfordert auch eine iede Harmonie, wenn sie gleich nur aus zwo Stimmen bestünde, eben solche Erörterung, Einwürffe, Beisprüche und Lutgefechte in den klängen, die man durch kein bessers Mittel, als durch die so genannte Nachahmung, welche mit ihren Kunstworte, Imitatio, vel potius Aemulatio vocum heisset, vorstellig machen kan.

\$.4. Diese Nachahmung nun hat in der Music dreierley zu bedeuten. Denn erstlich finden wir Gelegenheit, dergleichen Uibung mit allerhand natürlichen Dingen und Gemüths-Neigungen anzustellen, worin schier das grösseste Hülfsmittel der Erfindung bestehet, wie an seinem Orte gesaget worden ist. Fürs andre wird diejenige Bemühung verstanden, so man sich gibt, dieses oder jenen Meisters und Ton-Künstlers Arbeit nachzumachen: welches eine gantz gute Sache ist, so lange kein förmlicher Musicalischer Raub dabey mit unterläuff. Drittens bemercket man durch die Nachahmung denjenigen angenehmen Wettstreit, welchen verschiedene Stimmen über gewisse Förmelgen, Gänge oder kurtze Sätze mit aller Freiheit unter einander führen.

${ }^{14}$ Tradução Prof. Dr. Paulo Justi. 
Mattheson trata dos aspectos técnicos relativos à composição e relata o uso do termo imitatio de três maneiras distintas: como imitação de coisas naturais e afecçôes de ânimo; como imitação de obra de outro mestre ou compositor; e como imitação de vozes, sendo que esta última variante indica uma forma livre de imitação, enfatizada através do negrito impresso nas palavras mit aller ("com todos"), em referência às liberdades tomadas na imitação.

Assim, seguindo os preceitos aristotélicos de mimese e o raciocínio proposto por Mattheson da divisão das maneiras de imitação, podemos classificar as formas musicais nas quais se utiliza a imitação. Para fins de argumentação, subverteremos a ordem de Mattheson e discutiremos as categorias na seguinte ordem: (1) imitação de coisas naturais; (3) imitação de vozes e (2) imitação de mestre e/ou compositor.

\subsection{IMITAÇÃo de COISAS NATURAIS E AFECÇÓES DE ÂNIMO - A TRAGÉDia COMO ARTE IMITATIVA}

Como parte essencial das artes imitativas e, sobretudo, artes que imitam afecções de ânimo, encontra-se a tragédia que, como vimos, é a imitação que se efetua mediante açóes. Embora a tragédia não seja encarada como uma arte musical, tem na música um dos seus principais ornamentos ${ }^{15}$, pois é também através dela que os espectadores podem ser movidos em seus afetos.

Aristóteles, no Livro IV da Poética (1449a), discorre sobre a origem da tragédia, afirmando que ela "[...] se desenvolveu a partir de falas improvisadas do solista do ditirambo, evoluindo pouco a pouco, até que, passadas muitas transformações, se deteve e atingiu sua forma natural. É em verso, utiliza ritmo trímetro jâmbico e imita homens superiores."

Ao explanar a finalidade e superioridade da tragédia como arte imitativa, Aristóteles assinala:

A tragédia pode atingir a sua finalidade, como a epopéia, sem recorrer a movimentos [gesticulaçóes de atores], pois uma tragédia, só pela leitura, pode revelar as suas qualidades. [...] Mas a tragédia é superior [à epopeia] porque contém todos os elementos da epopéia (chega até a servir-se do metro épico), e demais, o que não é pouco, a melopeia e o espetáculo cênico, que acrescem a intensidade dos prazeres que lhe sáo próprios. Possui, ainda, grande evidência representativa, quer na leitura, quer na

\footnotetext{
${ }^{15}$ Aristóteles, na definição da tragédia (Poética, 1449b 30), indica a melopeia como parte essencial, contudo, na passagem (Poética, 1450b 15), ele a aponta como principal ornamento da tragédia.
} 
cena; e também a vantagem que resulta de, adentro de mais breves limites, perfeitamente realizar a imitação. (Poética, 1462a-b).

Assim, a tragédia, como arte que imita açôes de homens melhores, será usada como elemento pedagógico desde as diversas formas teatrais "religiosas" pagãs, como também, e principalmente, nas formas dramáticas cristãs, tais como Dramas Sacros, Paixóes e Missa.

\subsection{IMITAÇÁO DE VOZES}

Aristóteles, no Livro III da Retórica, discorrendo sobre os aspectos concernentes ao discurso ${ }^{16}$, avalia que o aspecto mais importante é o que diz respeito à pronunciação. Naturalmente, para que haja uma boa pronunciação do discurso, o orador deve fazer uso da voz e, para o Estagirita, "[...] a voz é, de todos os nossos órgãos, o mais apropriado à imitação." (Retórica, 1404a). Ele explicita:

A pronunciação assenta na voz, ou seja, na forma como é necessário empregá-la de acordo com cada emoção (por vezes forte, por vezes débil ou média) e como devem ser empregues os tons, ora agudos, ora graves ou médios, e também quais os ritmos de acordo de acordo com cada circunstância. São por conseguintes, três os aspectos a observar: são eles volume, harmonia e ritmo. Aqueles que, entre os competidores, empregam estes três aspectos arrebatam quase todos os prêmios [...].

Dessa forma, podemos observar que os aspectos referentes à pronunciação do discurso são análogos ao do discurso musical.

Na música, como frisado anteriormente, o procedimento da imitação, primeiramente vocal e depois instrumental, vem de longa data. Inicialmente, a imitaçáo é tratada como uma técnica composicional, pela qual uma parte de uma melodia se repete ou se sobrepóe, em geral numa altura diferente. Frequentemente, essas passagens repetidas são denominadas "imitativas".

Os termos mimesis, ethophonia ou imitatio também foram empregados para indicar um procedimento da retórica musical que tanto pode ser entendido

\footnotetext{
${ }^{16}$ Segundo Aristóteles, são três os aspectos concernentes ao discurso: o primeiro, de onde provêm as provas; o segundo é relativo à expressão enunciativa; o terceiro, à forma como convém forçosamente organizar as partes do discurso.
} 
como uma técnica composicional, confundindo-se com o procedimento da fuga ${ }^{17}$ ou do canon, quanto como uma figura de ornamento, ou mesmo harmônica, da retórica-musical.

Johann Mattheson, no final do último capítulo da segunda parte de seu tratado Der vollkommene Capellmeister, de 1739, aponta a mimesis como uma das figuras usadas na composição fugal. A estrutura da fuga é parte integrante da imitação musical e Bach, em suas obras, consegue atingir o apogeu dessa estrutura, chegando consequentemente também ao apogeu da imitação porém, não apenas da imitação como procedimento de composição musical, mas, através de suas paródias, igualmente da imitação retórica.

\subsection{Imitaçấo de mestre e/ou compositor - Contrafactum, Paródia e EMULAÇÃ́o}

Contrafactum e paródia são termos que, por princípio, foram utilizados para indicar atividades literárias, sendo apenas posteriormente indicativos de atividades musicais. Ambos, ao serem usados para substituir um texto por outro, mantendo-se a antiga melodia, assumem claramente a funçáo de tropo ${ }^{18}$ retórico musical, ferramenta que se encontra no cerne do desenvolvimento do drama sacro e também se fará presente em diversas formas, nas composições de Bach.

No que concerne à atividade musical, por definição, paródia e contrafactum são o resultado de uma melodia, ou toda composição, que foi tomada e reutilizada, alterada ou não. Tanto a paródia quanto o contrafactum são atividades que, mesmo no âmbito musical, geralmente estarão relacionadas com o emprego de algum texto. Durante o período da Reforma protestante, o contrafactum, funcionando como tropo, foi uma categoria particularmente

\footnotetext{
${ }^{17}$ A composição fugal é um dos primeiros artifícios musicais a ser associado com a disciplina da retórica. A primeira indicação do termo fuga com entendimento retórico parece surgir nos idos de 1536, com Stomius, que se referia ao termo fuga ou mimesis como uma figura retórica de repetiçáo (BARTEL, 1997, p. 277).

${ }^{18} \mathrm{O}$ tropo é uma mutação semântica, uma técnica de denominaçăo que consiste em tomar uma palavra com o sentido de outra, é um desvio, uma transposição da flecha semântica que liga uma palavra a seu significado e é substituída por uma ligação diferente. Desdobra-se em muitas espécies, sendo as mais importantes a metáfora, a metonímia e a sinédoque. Embora concebido como ferramenta retórica, aliado à música, criou uma forma primitiva de tragédia litúrgica católica, o "drama sacro". Essa forma trágica era musicada, encenada e inicialmente apresentada durante o serviço litúrgico católico, todavia, graças à sua transformação, desenvolveu outras formas dramático-musicais religiosas, tais como as Paixöes e o luterano Actus Musicus.
} 
importante na adaptação de cançóes profanas para corais luteranos, nos quais a melodia se conservava, porém, o texto era substituído por uma letra inteiramente nova, ou pelo menos alterada de maneira a conferir-lhe um sentido religioso (GROUT, 2001, p. 278).

Outra forma de imitação musical é a paródia. Por definição, no campo musical, paródia é um termo usado para remeter a uma técnica de composição envolvendo o uso de material pré-existente, primeiramente associada ao século XVI (SADIE, 1994, p.700). Apesar de a palavra grega paródia $(\pi \alpha \rho \omega \delta i \alpha)$ aparecer já no início do século IV a.C., é apenas na metade do século XVI que se iniciam as discussôes sobre sua utilização em atividade musical.

No século XVI, o procedimento de composição de missas polifônicas apresenta a adoção generalizada da paródia. Ainda que já fosse usada no século precedente, em geral tendo cançóes seculares como ponto de partida, a paródia permanecia tímida e não se distinguia claramente da utilização de monodias preexistentes. No século XVI, ao contrário, observa-se o empenho em explorar os modelos escolhidos, tanto em sua estrutura polifônica quanto em seus temas melódicos: não se hesita em citar literalmente certas passagens, para melhor desenvolvê-las em novas elaboraçóes contrapontísticas; tal processo de cópia e paródia foi muito usado por Bach e seus contemporâneos. Bach normalmente realizava as paródias entre obras sacras e seculares da seguinte maneira: música de Paixão era reutilizada como música de funeral; música de funeral era adaptada para se tornar música de Paixão; música composta em honra ao nascimento de um filho de governante era reutilizada mais tarde para celebrar o nascimento do Filho de Deus (BUTT, 1997, p. 90), ou seja, na transposição entre o texto original da melodia para um texto novo, é guardado um decoro da matéria e uma analogia temática. Werner Neumann, que estudou particularmente a questáo da paródia em Bach, distingue cinco modelos de operação (apud BASSO, 1985, v. II, p. 270):

I - reutilização de uma cantata sacra por uma outra cantata sacra;

II - reutilização de uma cantata profana por uma cantata sacra;

III - reutilização de uma cantata profana por uma cantata profana;

IV - reutilização de uma obra instrumental por uma obra vocal;

$\mathrm{V}$-reutilização de uma obra vocal por uma obra instrumental.

Como se nota, Bach jamais transforma cantatas sacras em profanas, demonstrando assim uma particular sensibilidade aos elementos espirituais 
de origem, os quais não podem ser "rebaixados" ao nível de obras profanas; estas, porém, podem ter seus elementos "elevados" ao nível de uma cantata sacra. Através desse mecanismo, fica evidente a importância dada por ele à adequação ao gênero do discurso, pois um discurso de gênero baixo poderia ou ser transformado em outro do mesmo gênero ou ser elevado, porém, o mesmo não ocorreria com um discurso elevado, o qual poderia, no máximo, ser transformado em outro do mesmo gênero, mas nunca ser rebaixado.

As composições de Bach não tinham a intenção primária de "deleite" de um público de concerto, mas sim a "edificação" de uma congregação de igreja. As cantatas foram concebidas náo como peças de concerto, mas como sermáo musical. Autores como Spitta comentam que Bach, mesmo ao compor obras seculares, escrevia de maneira sacra (BUTT, 1997, p. 90). O mecanismo da paródia será amplamente utilizado por Bach em várias obras, porém, pode ser observado com maior ênfase no Oratório de Natal, nas Missas Breves e, sobretudo, na "Missa em Si Menor".

No contexto de imitação proposto por Mattheson, através da cópia da obra de mestres ou modelos previamente compostos, podemos incluir o conceito de emulação.

Isócrates (436-338 a.C.), retórico ateniense, insistia em seus ensinamentos que a imitação deveria ser "grande, bela e humana", considerando-a como edificante, tanto moral como esteticamente. Dionísio de Halicarnasso (I a.C.-?), que ensinou em Roma antes do ano 30 a.C., em seu tratado Peri Mimeseos (Sobre a Imitação), define a mimesis como "[...] uma atividade de se fazer um modelo de exemplo por meio de observação." A ela poderia ser combinada a "emulação" (zelos), ou seja, "[...] uma atividade da alma, quando movida pela admiração do que parece ser belo." (KENNEDY, 2001, p.381-383). Observa-se, assim, que Isócrates e Dionísio de Halicarnasso começam a preocupar-se em tornar a beleza e a edificação moral como itens a serem observados, imitados e emulados no discurso.

A propósito da emulação, H. Brown (1982, p.8-10) explica que a prática de usar obras de grandes mestres como modelo e guia para estudantes pode bem ter sido a base para um princípio de pedagogia musical, no século XVI. Ele afirma que o princípio da imitação era bem conhecido em outros tipos de atividades intelectuais e artísticas, durante o período, todavia, acredita que nenhum teórico musical do século XV, ou mais tarde, no século XVI, tenha discutido essa técnica detalhadamente. Prova disso é que a maioria 
dos tratados em música da Idade Média e do início da Renascença iniciam igualmente com técnicas básicas necessárias para o entendimento, execução musical e vários aspectos da arte da composição musical, no entanto, sem apresentar nenhuma discussão teórica sobre a prática. Uma outra maneira de emulação aparece nos manuscritos de música secular do século XV, esta, por sua vez, era claramente não pedagógica, uma vez que envolvia um compositor maduro, o qual basearia uma nova composição em uma antiga composição de outro compositor maduro. $\mathrm{Na}$ verdade, os dois impulsos, imitação e emulação, são, sem dúvida, proximamente manifestados. Contudo, o ponto é que a emulação como homenagem era nitidamente uma técnica comum entre os compositores de canção do tardio século XV. O modo particular como os compositores se imitavam foi noticiado em instâncias isoladas, mas nunca foram analisados conjuntamente e, tampouco, vistos como parte de uma técnica-padrão do período.

Para H. Brown (1982, p.8-10), assim como os poetas e oradores, também os compositores aprenderam sua arte imitando os grandes mestres, moldando novas peças diretamente nos antigos. Ele argumenta que, entre os séculos XV e XVII, a ideia de criação de um trabalho musical totalmente novo, baseado em modelos pré-existentes, cresce da respeitável tradição retórica da imitatio, elaborada particularmente pelos humanistas.

A emulação, como um tipo de imitação ligada à moral, já ocorrera em Aristóteles, na Retórica:

A emulação consiste num certo mal estar ocasionado pela presença manifesta de bens honoríficos e que se podem obter em disputa com quem é nosso igual por natureza, não porque tais bens pertençam a outrem, mas porque também não nos pertencem (razão pela qual a emulação é uma coisa boa e própria de pessoas de bem [...]. (Retórica,1388 b).

Aristóteles, na Retórica, define a emulação como uma espécie de inveja positiva, isto é, a imitação pela posse de bens. Para ele, emular é admirar (Retórica, 1385a). Porém, ele não se limita a tratar da emulação apenas no sentido de posse, pois, logo em seguida, acrescenta:

Ora, se os bens honoríficos provocam emulação, necessariamente também as virtudes semelhantes a provocarão e tudo quanto é útil e benéfico aos outros (porque as pessoas têm em consideração os benfeitores e as pessoas de bem). E o mesmo acontece com todas as coisas boas que podemos 
usufruir com os que estão próximos de nós, por exemplo, a riqueza e a beleza, mais até que a saúde. (Retórica, 1388b).

Aristóteles não trata da emulação em sua Poética, mas há um similaridade com a questão da imitação (mimesis) como podemos observar:

[...] e, estando nós em posse, conforme à natureza do imitar, da melodia e do ritmo (pois é evidente que os metros fazem parte do ritmo), desde o início os mais naturalmente dotados para tais coisas, progredindo aos poucos, engendraram a composição a partir das improvisaçóes. Mas a composiçáo desmembrou-se segundo os caracteres apropriados: os mais solenes imitavam as açóes nobres e de pessoas desse tipo, enquanto os menos exigentes as das pessoas ruins, inicialmente compondo injúrias, assim como os outros hinos e encômios. (Poética IV, 1448b20-7).

Podemos supor que, ao incluir a beleza em sua lista de bens emuláveis, Aristóteles dá um importante passo na direção do que será, bem mais tarde, a Estética, e sua influência será percebida em autores posteriores, como o já visto anteriormente, Dionísio de Halicarnasso ((apud VELOSO, 2004, p. 241), o qual, em sua obra Sobre a Imitação, afirma:

A imitação é a atividade que guarda o modelo por meio das regras, mas, como dizem os sucessores, discurso ou ação que contem uma semelhança bem sucedida com o modelo. Emulação é a atividade de uma alma movida para admiraçáo pelo que ela acha que é belo.

Dessa forma, podemos imaginar que, sendo a beleza um bem emulável, assim também poderemos tratar todas as manifestaçóes artísticas, incluindo a música.

Bach, ao realizar suas paródias, segue o princípio emulativo, visando sempre, ao adaptar obras previamente compostas, à qualidade, ou, como destaca Aristóteles, o bem. O modelo musical a ser parodiado é um paradigma, uma amostra com base na qual escolhemos certa coisa. Se, para Aristóteles, pelo paradigma se aprende, conforme mencionado desde o início, na Poética, para Bach, a paródia é um paradigma onde igualmente a mensagem religiosa nela contida está assegurada de ser transmitida.

Podemos notar uma analogia entre a teoria aristotélica da emulação e as paródias realizadas por Bach, já que Bach não faziaa uma simples cópia de 
uma obra anterior, mas, ao contrário, em sua reutilização, sempre procurava a adequaçáo e a melhoria do discurso. Como vimos, tais preceptivas de imitação/paródia do discurso, com base na adequação, unidade, beleza e preceitos morais, também foram encontradas na teoria de diversos retóricos posteriores a Aristóteles.

A paródia bachiana é uma imitação de caráter emulativo, porque não se trata de mera repetiçáo de trechos musicais em alturas diferentes, como previsto nos tratados de composição, mas de uma escolha criteriosa, carregada de valores morais e que leva em conta tanto os preceitos da composição quanto os da retórica musical. Essa atitude de Bach mantém um completo alinhamento com as preceptivas de Aristóteles encontradas na Poética e na Retórica, as quais perpassaram tantos autores e compositores, ao longo da história, como demonstrado.

Todos esses fatores a respeito das formas imitativas musicais, aliados à técnica composicional de Bach e aos preceitos poéticos aristotélicos, levam-nos a acreditar ser possível considerar a "Missa em Si Menor" uma verdadeira tragédia, sendo ambas, tragédia e missa, imitaçôes de ações de caráter elevado, que têm na música um principal elemento. Sabe-se que Bach estudava retórica, e o quanto conhecia de Aristóteles não está documentado. No entanto, a proximidade de Bach com o teórico Johann Gottsched sugere um conhecimento de ideias do Estagirita pelo compositor, pois é inegável a semelhança de conduta de ambos, no valor dado à imitação, no seu caráter específico de emulação e, principalmente, no procedimento moral ao empregálas. Assim, através dos preceitos imitativos preconizados por Aristóteles, em sua Poética, e as diversas formas de imitação musical, sobretudo as utilizadas pelos compositores da Musica Poetica, podemos observar uma clara aproximação entre a poética e a música. 
KATO, Katia. Musical mimesis. Trans/Form/Ação, Marília, v. 39, p. 93-110, 2016. Edição Especial.

\begin{abstract}
Music occupies a prominent place as a means of imitation. The use of music as a tool to inspire and represent affections, which has occurred since ancient times, was integral to eighteenth century music. This can be clearly seen in the works of German composers linked to the compositional doctrine of musica poetica, and especially in the work of Johann Sebastian Bach. However, there are several kinds of musical imitation. Therefore, the purpose of this study is to categorize and define the function of imitation, based on the Aristotelian concept of imitation and on the categories of imitation proposed by Johann Mattheson, one of the main theoreticians of musica poetica. We try to show that ever since the musical conceptions of antiquity, music and poetics have been inseparable.
\end{abstract}

KEYWORDS: Musical mimesis. Aristotle. Musica poetica. Johann Sebastian Bach.

\title{
REFERÊNCIAS
}

ARISTÓTELES. Política. Tradução de Torrieri Guimarães. São Paulo: Hemus, 1966.

. Retórica. Tradução de Manuel Alexandre Júnior. Lisboa: Imprensa Nacional - Casa da Moeda, 1998.

. Poética. Tradução de Eudoro de Souza. Lisboa: Imprensa Nacional; Casa da Moeda, 2003.

. Metafisica. Tradução de Edson Bini. São Paulo: Edipro, 2006.

. Ética a Nicômaco. Tradução de António de Castro Caeiro. São Paulo: Atlas, 2009.

BARTEL, D. Musica poetica. Nebraska: University of Nebraska Press, 1997.

BASSO, A. Jean Sébastien Bach. V. II. França: Librairie Arthème Fayard, 1985.

BROWN, H. M. Emulation, competition and homage: imitation and theories of imitation in the Renaissance. Journal of the American Musicological Society, USA, v. 35, n. 1, p.1-48, 1982.

BUTT, J. (Ed). The Cambridge companion to Bach. Cambridge: Cambridge University Press, 1997.

FALCK, R. Parody and contrafactum: a terminological classification. The Musical Quarterly, v. 65, n. 1, p.1-21, jan. 1979.

GOTTSCHED, J. C. Versuch einer Critischen Dichtkunst. Darmstadt: Wissenschaftliche Buchgesellschaft, 1962.

GROUT, D. J.; PALISCA, C. V. História da musical ocidental. Lisboa: Gradiva, 2001.

HARVEY, P. Dicionário Oxford de literatura clássica grega e latina. Rio de Janeiro: Jorge Zahar, 1987. 
KATO, K.

KENNEDY, G. A. Imitation. In: SLOANE, T. O. Encyclopedia of thetoric. New York: Oxford University Press, 2001. p. 381-384.

MATTHESON, J. Der vollkommene Capellmeister. Kassel: Bärenreiter, 1999.

SADIE, S. Dicionário Grove de música. Rio de Janeiro: Jorge Zahar, 1994.

SEGRE, C. Enciclopédia Einaudi. V. 17. Lisboa: Imprensa Nacional; Casa da Moeda, 1989.

VELOSO, C. W. Aristóteles Mimético. São Paulo: Discurso, 2004. 